TERMINUS

t. 21 (2019), z. 1 (50), s. 41-65

doi:10.4467/20843844TE.19.002.10502

www.ejournals.eu/Terminus

Justyna Kruk-Siwiec

http://orcid.org/0000-0003-2318-3316

Uniwersytet Jagielloński, Kraków

justyna.kruk@doctoral.uj.edu.pl

\title{
Obrońcy i ciemiężyciele, czyli o dualistycznym modelu historii chłopów (i niektórych jego niedostatkach z perspektywy historii literatury $)^{1}$
}

\begin{abstract}
Defenders and Oppressors, or the Dualistic Model of Peasant History (and Some of Its Deficiencies from the Perspective of Literary History)
\end{abstract}

Since the beginning, peasant studies in Poland have been an area of research determined to a particularly high degree by the socio-political context. These specific conditions for the development of this discipline have developed a characteristic narrative framework, which has a visible influence on the historiography devoted to peasants. One such schema is the dualistic division of old-Polish writers into defenders and ideological oppressors of the lowest estate, particularly noticeable in the $19^{\text {th }}$ and $20^{\text {th }}$-century historical literary research. This paper is an attempt to describe and at the same time deconstruct this division, considered here as one that is ahistorical and therefore hinders in-depth research on the old-Polish discourse on the peasant state. The conclusions present several other ways to study old texts on the peasantry.

Keywords: peasants, historiography, old-Polish literature, peasant studies

${ }^{1}$ Serdecznie dziękuję dr. Tomaszowi Nastulczykowi za cenne komentarze do niniejszego artykułu. 
Historyk piśmiennictwa staropolskiego usiłujący zmierzyć się $\mathrm{z}$ problemem obrazowania stanu chłopskiego w tekstach dawnych prędzej czy później stanie w obliczu metodologicznego impasu. Oto bowiem tradycja badawcza (rozumiana szeroko, jako badanie historii chłopów), z którą należy się zapoznać, sięga, skrupulatnie licząc, końcówki XVIII wieku². Kolejne stulecie obfituje już w dziesiątki broszur poświęconych dziejom włościan lub przynajmniej pośrednio ich dotyczących ${ }^{3}$ oraz pierwsze próby syntetycznego ujęcia historii tego stanu ${ }^{4}$. Na okres przedwojenny należałoby datować pionierskie prace poświęcone szczegółowo obrazowaniu chłopów w literaturze ${ }^{5}$, historiografia marksistowska dostarczyła zaś obfitej bazy źródłowej dotyczącej tego zagadnienia ${ }^{6}$. Problem jednak w tym, że przeważają-

${ }^{2}$ Historia chłopów polskich, t. 1: Do upadku Rzeczypospolitej szlacheckiej, red. S. Inglot, oprac. J. Burszta et al., Warszawa 1970, s. 7.

${ }^{3}$ Jak o tym świadczą obszerne spisy Wacława Aleksandra Maciejowskiego: Broszury ze sprawa włościańska ściśle zwiazane $i$ wprost ja obchodzace oraz Broszury ubocznie się sprawy włościańskiej dotykające zamieszczone w Dodatkach do jego Historyi włościan i stosunków ich politycznych, społecznych i ekonomicznych, które istniaty w Polsce od czasów najdawniejszych aż do drugiej połowy XIX wieku, Warszawa 1874, s. 336-383.

${ }^{4}$ E. Stawski, Poszukiwania do historyi rolnictwa krajowego, Warszawa 1858; J.T. Lubomirski, Rolnicza ludność w Polsce od XVI do XVIII wieku, Warszawa 1862; W.A. Maciejowski, Historya włościan i stosunków ich...; W. Przyborowski, Włościanie u nas i gdzieindziej. Szkice historyczne, Wilno 1881. Jako szczególnie przełomowe dla ukonstytuowania się dla badań chłopskich w obrębie historiografii narodowej wskazuje się zazwyczaj Uwagi nad dziejami Polski i ludu jej Joachima Lelewela (w: idem, Polska. Dzieje i rzeczy jej rozpatrywane, t. 3, Poznań 1855). Zob. Historia chłopów..., s. 7-8.

${ }^{5}$ W. Nartowski, Stan włościański w utworach poetyckich pisarzy polskich doby renesansowej (XVI wieku), „Lud. Kwartalnik etnograficzny” 19 (1913); M. Urbanek, Chłop w literaturze złotego okresu, w: Sprawozdania dyrekcji c. k. Gimnazyum w Sanoku za lata szkolne 1913/1914 i 1915/1916; S. Kot, Polska rajem dla Żydów, piektem dla chłopów, niebem dla szlachty, Warszawa 1937, oraz częściowo idem, Urok wsi i życia ziemiańskiego w poezji staropolskiej, Warszawa 1937, a także obszerne fragmenty rozprawy A. Świętochowskiego Historja chłopów polskich w zarysie, t. 1, Lwów 1925.

${ }^{6}$ S. Szczotka, Lament chtopski na pany oraz inne narzekania na niedole poddanych polskich, Warszawa 1946; Obrońcy chłopów w literaturze polskiej, zest. i oprac. M. Piszczkowski, Kraków 1951; S. Czernik, Pięć wieków doli chłopskiej w literatu- 
ca większość tej wcale bogatej literatury przedmiotu nie funkcjonuje we współczesnych badaniach nad literaturą dawną. Duże znaczenie ma tutaj naturalny fakt dezaktualizacji niektórych hipotez czy syntetyzujących wniosków ze względu na nowsze metodologiczne lub też źródłowe ustalenia. Nie sposób jednak nie zwrócić uwagi na poważniejszy i bardziej skomplikowany problem badań chłopskich, jakim jest historyczne uwikłanie tego zagadnienia w szeroko pojęty kontekst polityczny. W pierwszej kolejności można odnieść wrażenie, że uwaga ta dotyczy wyłącznie, lub przede wszystkim, historiografii marksistowskiej (zwłaszcza z pierwszych lat powojennych), w której temat chłopów w literaturze jawi się jako wymuszony ideologicznie i narzucony badaczom przez czynniki wobec nauki zewnętrzne. Istotnie: po fali publikacji owocujących licznymi pracami historyków literatury staropolskiej na temat wsi i chłopa następuje okres niemal całkowitego zarzucenia tej problematyki trwający (w obrębie tej dyscypliny) z nielicznymi wyjątkami do dzisiaj ${ }^{7}$. Jednak po bliższym zapoznaniu się z dawniejszą, zwłaszcza dziewiętnastowieczną, historiografią staje się jasne, że temat chłopski od momentu jego wyłonienia był jak najściślej związany z konkretnymi programami politycznymi i jako taki bezpośrednio przez nie warunkowany. Co więcej, badacze marksistowscy, jakkolwiek sami sytuowali swoje badania chłopskie w kategoriach ideologicznego i metodologicznego przełomu, zaskakująco często posługiwali się ramami narracyjnymi

rze XII-XVI wieku. Materiały i szkice, Warszawa 1953; M. Rękas, Obrońcy chłopów $w$ dobie polskiego Odrodzenia, Warszawa 1954; S. Czernik, Z życia pańszczyźnianego w XVII wieku. Materiały i szkice, Warszawa 1955; „Wzięli diabli pana”. Antologia poezji walczacej o postęp i wyzwolenie społeczne 1543-1953, oprac. S. Czernik, J. Przyboś, Warszawa 1955; Wieś pańszczyźniana w literaturze polskiej (w. XV-XIX), oprac. i wstęp M. Piszczkowski, Warszawa 1972; S. Grzeszczuk, Obrońcy chłopów w piśmiennictwie staropolskim, w: idem, Materiały do studiowania literatury staropolskiej, cz. 1, Rzeszów 1976.

7 J. Matuszewski, Cham, Łódź 1991; D. Chemperek, Z chłopki księżna. Historia wielkiej mistyfikacji XVII wieku, Lublin 2000; S. Baczewski, Obraz plebejusza w literaturze szlacheckiej: rekonesans, „Napis. Pismo poświęcone literaturze okolicznościowej i użytkowej” 15 (2009). 
wypracowanymi przez przedwojenne, a nawet wcześniejsze tradycje badawcze. Być może był to element świadomej gry z systemem - chęć ocalenia ciągłości dyscypliny w odmiennych i zapewne trudnych dla badaczy warunkach historycznych. Obserwacja powyższa może jednak równie dobrze świadczyć o uporczywej, nieuświadomionej obecności pewnych struktur narracyjnych w polskiej historiografii.

Celem niniejszego artykułu jest prześledzenie jednej z takich struktur. Jest nią dualistyczny schemat poznawczy, dzielący pisarzy staropolskich na obrońców chłopów i wyrazicieli ideologii stanowej szlachty. To znamienne rozróżnienie stworzone z konkretnym ideologicznym przesłaniem przez historiografię dziewiętnastowieczną zostało przejęte i w sposób szczególny ugruntowane przez historyków marksistowskich. Zważywszy zaś, że problematyka chłopska w badaniach literaturoznawczych nad piśmiennictwem staropolskim stanowi obecnie swoistą białą plamę, można założyć, że opisywane rozróżnienie do dzisiaj organizuje nasze myślenie o pisarzach staropolskich w kontekście chłopów ${ }^{8}$. Tymczasem binarny schemat obrońcy-ciemiężyciele, jakkolwiek przez lata sankcjonowany liczny-

${ }^{8}$ Dotkliwy brak współczesnych badań poświęconych kategorii chłopskości w staropolszczyźnie sprawia, że współcześni kulturoznawcy i literaturoznawcy analizujący to zagadnienie, odwołując się do tekstów dawnych, siłą rzeczy opierają się na ustaleniach historyków przedwojennych i marksistowskich. Zob. na przykład tekst Pawła Tomczoka, Pańszczyzna i przemoc. Historie literackie $i$ wspomnieniowe $z$ XIX wieku, „Praktyka Teoretyczna” 1 (2017), s. 237-266, czy prace odwołujące się do kanonu obrońców chłopów: W. Kuligowski, Chamska historia Polski. Tezy i antytezy, „Czas Kultury” 3 (2016), s. 70-77; K. Pobłocki, Niewolnictwo po polsku, „Czas Kultury” 3 (2016), s. 60-66. Jeszcze poważniejszym problemem metodologicznym wydaje się zupełne pomijanie - konstytutywnego dla chłopskości - tła historycznego, jakim był dyskurs stanowy. Zob. monograficzny numer „Tekstów Drugich” 6 (2017): Chłopskość. Brak odwołań do społecznego i dyskursywnego kontekstu I Rzeczypospolitej jest tu zauważalny chociażby w artykule Anny Engelking, „Poleszczuk” nieoswojony. Wokół funkcji chłopskości w konstruowaniu polskości, w którym autorka analizuje wielopłaszczyznową stereotypizację mieszkańców Polesia. Język ten w dużej mierze jest kontynuacją dawnego, staropolskiego dyskursu na temat chłopa w ogóle (topos arkadyjski, odmienność natury, zwierzęcość). Warto więc odnotować, że dopiero w XIX wieku, kiedy na dobre upowszechniła się idea unarodowienia ludu, ten styg- 
mi przykładami, które mocno utrwaliły się w powszechnej świadomości, raczej komplikuje zrozumienie, niż wyjaśnia logikę szlacheckiego dyskursu na temat stanu chłopskiego. Co więcej, staje się on źródłem tyleż licznych, co w gruncie rzeczy sztucznych problemów badawczych. Twierdzenia te postaram się uzasadnić na konkretnych przykładach źródłowych, sformułuję także w konkluzji rodzaj metodologicznej kontrpropozycji.

Zacznę jednak od genezy. Jak już zostało wspomniane, dziewiętnastowieczne badania chłopskie pozostawały w ścisłych związkach z warunkującymi je kontekstami ideologicznymi. Nader ciekawym przejawem tego stanu rzeczy był zainicjowany w 1857 roku przez Poznańskie Towarzystwo Przyjaciół Nauk konkurs na najlepszą monografię poświęconą „historii włościan i stosunków ekonomicznych w dawnej Polsce" 9 . Komisja konkursowa wypracowała szczegółowe merytoryczne instrukcje dla potencjalnych autorów pracy. Wgląd $\mathrm{w}$ te dokumenty nie pozostawia wątpliwości: dziewiętnastowieczni moderatorzy historii chłopów otwarcie łączyli ją z najbardziej wówczas palącymi kwestiami natury społecznej i gospodarczej. Autor tych wskazówek, Stanisław Egbert Koźmian, w referacie Jak traktowana być winna historia włościan $w$ Polsce stwierdzał, że w czasach „wiekowego zadania” (jakim są projektowane reformy społeczne) nie wystarczy powoływać się na argumenty ekonomiczne czy moralne. Promotorzy poprawy losu włościan muszą także sięgnąć do wiedzy o przeszłości, tak by uwłaszczenie i nadanie praw obywatelskich chłopom jawiło się ,jako naturalne, logiczne następstwo całego ducha i ciągu dziejów ojczystych"10. Aby osiągnąć ten cel, autorzy przyszłych monografii winni swoje badania oprzeć na zaprojekto-

matyzujący język został stopniowo przekierowany na inne (niepolskie) grupy etniczne, „wzbogacając się” przy tym o elementy takie jak egzotyzacja.

9 Z. Gołębiowska, Jak pisać historię chłopów polskich? Uwagi i refleksje Stanisława Egberta Koźmiana, „Annales Universitatis Mariae Curie-Skłodowska. Sectio F” 54/55 (1999/2000), s. 188.

${ }^{10}$ Instrukcje S.E. Koźmiana, Biblioteka Naukowa PAU i PAN w Krakowie, sygn. BPANKr, rkps 2212/7, k. 24r. 
wanym przez Koźmiana schemacie narracyjnym, dzielącym dzieje chłopów na trzy epoki. Pierwszą z nich stanowił w jego ujęciu „stan stosunkowo błogi” - swoisty wiek złoty w dziejach chłopów trwający od czasów słowiańskich do panowania Kazimierza Wielkiego. Zasadniczą funkcją tej części wywodów miałoby być udowodnienie, że „pierwiastkowo niewola nie istniała, i że ją przejęto w Polsce od obcych, gdy coraz częstsze i krwawsze najazdy sąsiadów, którzy ludność rolniczą uprowadzali, zmusiły ówczesne rycerstwo do odwetu"11. Jako czarną kartę w historii ludu należało z kolei przedstawić epokę supremacji władzy szlachty (od czasów Ludwika Węgierskiego). W rozdziale tym oczekiwano od autorów szczegółowego zdania sprawy z błędów królów i stanu obywatelskiego, które doprowadziły do „odsunięcia zupełnego od praw krajowych najliczniejszej, najpracowitszej klasy"12. Wreszcie w zgoła odmiennych barwach odmalować należało epokę ostatnią - czasy dążeń reformatorskich, w których na zasadzie kontrastu potencjalni autorzy winni podkreślić powszechne niemal zaangażowanie ziemiaństwa w poprawę losu chłopów ${ }^{13}$.

W proponowanym przez Koźmiana modelu historii chłopów, w której każda z epok spełniała określone funkcje dyskursywne, ważne z punktu widzenia bieżącej debaty politycznej (pierwsza legitymizowała pożądane przez stronnictwa demokratyczne powszechne obywatelstwo włościan, druga potępiała moralnie pańszczyznę i pozbawienie chłopów ochrony prawnej, trzecia zaś zachęcała do poparcia koniecznych reform), szczególnie interesująca jest część druga.

11 Ibidem, k. 25r.

12 Ibidem, k. 26r.

13 „O ile w drugiej epoce będzie smutnym pisarza obowiązkiem wytykać samolubstwo, brak zdrowych pojęć, a częstokroć i wznioślejszych w szlachcie uczuć, o tyle znowu w tym ostatnim okresie przyjdzie mu odmalować pocieszającemi rysami jej wytrwałość w raz powziętym zamiarze, pomimo ciągłych zawad i zniechęceń, jej dobrowolne i niemal jednomyślne zrzeczenie się wszelkich przywilejów, jej wreszcie skwapliwości do brania inicjatywy w przedmiocie reformy stosunków włościańskich, ilekroć tylko pozwolono jej wynurzyć ożywiające ją nadzieje i życzenia”, ibidem, k. 26r.-26v. 
Mroczną dla chłopów epokę demokracji szlacheckiej radził bowiem autor instrukcji rozjaśnić za pomocą kilku zabiegów. Sąd o polskiej szlachcie złagodzić mogło po pierwsze porównanie społecznych realiów I Rzeczypospolitej z równie okrutnymi stosunkami społecznymi panującymi w krajach ościennych ${ }^{14}$. Koźmian w drugiej części projektowanej rozprawy sugerował także „wyświetlić błogie przymioty patriarchalnego stosunku między szlachtą a włościaństwem, które chociaż poddaństwa nigdy nie usprawiedliwiają, mają niekiedy czynić go znośnym [...]"15. Ostatnim wreszcie sposobem na ocieplenie wizerunku Rzeczypospolitej szlacheckiej miało być skrupulatne zebranie wszelkich dowodów źródłowych zaświadczających, że „miłość bliźniego, poświęcenie, przezorność polityczna posiadały w najgorszym okresie swoich rzeczników i świetne radziły przykłady" ${ }^{16}$. Autor przyszłej monografii powinien więc z jednej strony dokonać wszechstronnej i gruntownej krytyki systemu folwarczno-pańszczyźnianego, z drugiej zaś zebrać i uwypuklić wszelkie dowody humanitarnego stosunku do chłopów, konstruując tym samym rodzaj pozytywnej narracyjnej i zarazem moralnej przeciwwagi. Ten właśnie wyraźnie ambiwalentny charakter części poświęconej czasom demokracji szlacheckiej stał się, moim zdaniem, źródłem popularnego przez lata schematu, dzielącego twórców staropolskich na dwa antagonistyczne obozy obrońców i ciemiężycieli chłopów.

Za dobrą monetę wziął go w pierwszej kolejności zwycięzca konkursu Wacław Aleksander Maciejowski, który w nagrodzonej Historyi włościan (1874) czasy Rzeczypospolitej szlacheckiej nazwał okresem „grzechów politycznych, który Polska od zgonu ostatniego z Jagiellończyków po mieczu aż do upadku swego [...] popełniając ciągle, wystawiała się na długie cierpienia" ${ }^{17}$. Równocześnie we wstępie do monografii historyk zaznaczał:

\footnotetext{
14 Ibidem, k. 26r.

15 Ibidem, k. 25v.

16 Ibidem.

17 W.A. Maciejowski, Historya włościan i stosunków ich..., s. 135.
} 
Przeciwko takiemu bezprawiu [tj. narzuceniu chłopom przymusowych dni roboczych - J.K.-S.], równie zasadom towarzyskiej społeczności, jak i polityce kraju szkodliwemu, powstając, pisarze nasi, świeccy i duchowni, którzy w drugiej połowie XVI wieku żyli, i tak poddaństwo, jak i robociznę narzuconą uchylić radząc, przekonali wreszcie sejm, że się do zdania królów za włościańskim stanem zawsze obstających nachyliwszy, zapragnął szczerze wyrwać go $\mathrm{z}$ niedoli ${ }^{18}$.

I choć imiennie wzmiankuje tu jedynie dwóch takich szlachetnych mężów stanu - Jana Ostroroga i Andrzeja Zamoyskiego - sugeruje zarazem istnienie ciągłości wielowiekowej tradycji myślowej walczącej z egoizmem stanowym szlachty ${ }^{19}$. Ten schematyczny jeszcze u Maciejowskiego obraz dość szybko wypełnia się katalogiem postaci przywoływanych przez kolejne syntetyczne ujęcia historii chłopów. Walery Przyborowski w pracy Włościanie u nas i gdzieindziej (1881) wymienia tu na pierwszym miejscu Andrzeja Frycza Modrzewskiego, uznawanego odtąd niemal jednogłośnie za najważniejszego wśród staropolskich obrońców chłopów ${ }^{20}$. Prócz niego do grona „polityków serca” - jak określa jednego z pisarzy zalicza Przyborowski: Jakuba Przyłuskiego, Sebastiana Petrycego, Piotra Skargę, Fabiana Birkowskiego, Szymona Starowolskiego oraz Krzysztofa Opalińskiego. Wyliczeni mówcy i uczeni będą odtąd stanowili rodzaj „żelaznego kanonu” staropolskich twórców ujmujących się za chłopem. Autor Włościan u nas i gdzieindziej w symptomatyczny sposób uzasadnia także skonstruowanie powyższej listy:

Bądź co bądź jednak w tej smutnej, w tej rozkładowej chwili widzimy, że byli pisarze, odzywały się z pośrodka dumnych, wojennych okrzyków szlachty ciągnącej pod Pilawce, głosy wzywające do reform, skarżące się na ucisk.

18 Ibidem, s. 6.

19 Tradycji, która zresztą w jego ujęciu zwyciężyła ostatecznie nad egoizmem szlacheckim, za co uznaje Maciejowski reformy w dobrach Andrzeja Zamoyskiego oraz ogólne deklaracje Konstytucji 3 maja w sprawie włościańskiej; zob. ibidem, s. 7.

20 W. Przyborowski, Włościanie u nas i gdzieindziej..., s. 109. 
I powiedzmy, że żaden naród w tej dobie nie przedstawia podobnego przykładu, że w żadnym narodzie nie znajdziesz w XVI i XVII wieku tak bogatej literatury przeciw uciskowi, jak u nas. Jest to pociecha dla serca, dla uczucia narodowego, że ta okrzyczana przez nieprzyjaciół szlachta polska, z ucisku chłopa, przez usta najlepszych, a nawet najgorszych swych dzieci wypowiada słowa szczerego oburzenia na fatalny kierunek, w którym społeczny stan kraju poszed $2^{21}$.

Krytyka moralna szlachty w kontekście jej stosunku do chłopów nie może być ostatecznie druzgocząca w obliczu tak licznego oporu wybitnych jednostek - zdaje się sugerować autor. Obszerne wzmianki o pisarzach wstawiających się za najniższym stanem pozwalają więc w pełni napiętnować ucisk pańszczyźniany, a zarazem stają się podstawą do konstruowania pozytywnej płaszczyzny historycznego odniesienia.

Do takiego „katalogu” odwołał się także Kazimierz Józef Gorzycki w swoim Zarysie historyi chłopów w dawnej Polsce 22 (1902). Znacznie rozszerzył go zaś Aleksander Świętochowski w Historii chłopów polskich $w$ zarysie (1925), omawiając szczegółowo w kolejnych rozdziałach swojej syntezy pisarzy z XVI, XVII i XVIII wieku $^{23}$. Ta rozbudowana i utrwalona w pracach historyków tradycja badawcza miała zapewne swój wpływ także na rozpoznania literaturoznawców pierwszej połowy XX wieku, którzy podjęli refleksję nad obrazowaniem chłopskości w staropolskich źródłach literackich. Widać to w rozprawach takich badaczy jak Michał Urbanek czy Wacław Nartowski, u których prócz analizy konwencji estetycznych wyraźnie zaznacza się także potrzeba umiejscowienia postaci badanego twórcy w ramach omawianego dualistycznego schematu. Do obrońców chłopów nie można na przykład zaliczyć Piotra Roizjusza, który:

${ }^{21}$ Ibidem, s. 117.

22 K.J. Gorzycki, Zarys historii chłopów w dawnej Polsce do zniesienia poddaństwa, Warszawa 1902, s. 99.

23 A. Świętochowski, Historja chłopów polskich..., s. 192-221, 311-324. 
Choć pozna chłopów (rustici), a nawet zaopatrzy polecającym wierszem pismo Frycza o mężobójstwie, sam nie przejmie się zasadami broszury zachwalanej, lekceważąc stan kmiecy, co nie umiał ani uznać jego wiedzy i talentu, ani wynagrodzić za względy złotem ${ }^{24}$.

Był nim zaś niewątpliwie Sebastian Fabian Klonowic, któremu

[z]awsze przyświecały hasła miłości chrześcijańskiej i zgody społecznej, również i wolności wszystkich, a nade wszystko hasła głęboko pojętej sprawiedliwości. [...] To wszystko, co powiedział w obronie ludu, wskazuje, że miał serce współczujące $\mathrm{z}$ niedolą i z nędzą ciemiężonych, że wyżej cenił poczucie sprawiedliwości nad względy szlachty, że miał wiele odwagi cywilnej, by wbrew ówczesnym pojęciom głosić hasła wolności i równości ${ }^{25}$.

Ramy narracyjne wtłaczające staropolskich twórców i teksty poświęcone chłopom w naszkicowany tu dualistyczny model wzmocniła jeszcze metodologia marksistowska odwołująca się do dialektyki postępu i zacofania. Po zakończeniu II wojny światowej, zwłaszcza zaś w pierwszych latach powojennych, studia staropolskie zapełniły się licznymi pracami badawczymi i antologiami tekstów źródłowych poświęconych problematyce wsi i chłopa. Tytuły mówią tu same za siebie: Lament chłopski na pany oraz inne narzekania na niedole poddanych polskich (1946), Obrońcy chłopów $w$ literaturze polskiej (1951), Pięć wieków doli chłopskiej w literaturze XII-XVI wieku (1953) czy „Wzięli diabli pana”. Antologia poezji walczacej o postęp $i$ wyzwolenie społeczne 1543-1953 (1955) ${ }^{26}$. Mimo proklamowanego wówczas powszechnie przełomu metodologicznego w naukach społecznych, a niekiedy nawet bardziej radykalnych gestów odcięcia się od „szlacheckiej i burżuazyjno-obszarniczej historiografii" ${ }^{27}$, nietrudno zauważyć, że kanon obrońców zostaje, jak już zostało wspomniane, odziedziczony po badaczach

\footnotetext{
24 W. Nartowski, Stan włościański..., s. 99.

25 M. Urbanek, Chłop w literaturze..., s. 17.

${ }_{26}$ Zob. przypis 5.

27 M. Rękas, Obrońcy chłopów..., s. 5.
} 
wcześniejszej generacji (pojawiających się zresztą w przypisach i bibliografiach omawianych prac). Wyraźny wpływ marksizmu na odmienny, lub raczej zmodyfikowany, dobór źródeł w tym zakresie uwidacznia się w nielicznych jedynie ujęciach. Przykładem takiej zależności jest opublikowana w 1954 roku praca Michała Rękasa, Obrońcy chłopów w dobie polskiego Odrodzenia, której autor skrupulatnie pominął wszystkich klasycznych już obrońców katolickich (takich jak Skarga, Birkowski czy Starowolski) jako przynależnych do reakcyjnego obozu magnacko-kościelnego ${ }^{28}$. Nazwiska te jednak pojawiają się zazwyczaj w podobnych zestawieniach. Ciekawy jest także przypadek Kochanowskiego - włączanego w okresie powojennym w poczet twórców walczących w słusznej sprawie chłopskiej ze względu na swoją wyjątkową pozycję w kanonie pisarzy staropolskich ${ }^{29}$. Badacze marksistowscy rozmaicie radzili sobie z faktem, że w ogromnej spuściźnie mistrza czarnoleskiego niewiele jest w gruncie rzeczy wersów poświęconych tematyce chłopskiej. Jedni pisali więc o „dyskretnej, prawie zamaskowanej krytyce systemu folwarcznego w Pieśni świętojańskiej”30, inni sugerowali, że poeta pomijał ten problem jako oczywisty postulat reformatorski stronnictwa egzekucyjnego, do którego należał ${ }^{31}$. Abstrahując jednak od skomplikowanej kwestii wpływu metodologii marksistowskiej na interpretację zebranych źródeł, wypada podsumować, że sam model binarnego zorganizowania tekstów i twórców

${ }_{28}$ Zob. ibidem, s. 92-183.

${ }^{29}$ Wcześniejsi badacze raczej ubolewali nad tym, że „[p]ierwszy prawdziwy poeta polski, kochanie wieku: Jan Kochanowski, jak gdyby nie widział społecznej doli chłopa, o którym tylko mimochodem napomknie i to rzadko", W. Nartowski, Stan włościański..., s. 99.

30 S. Czernik, J. Przyboś, Wstęp, w: „Wzięli diabli pana”. Antologia poezji walczacej o postęp..., s. 7.

${ }^{31}$ „Nie wyłączał on tej [chłopskiej - J.K.-S.] sprawy i specjalnie nie podkreślał, ponieważ w jego przekonaniu stanowiła ona jeden $\mathrm{z}$ głównych składników programu reform stronnictwa egzekucyjnego, które w okresie najwyższej swej żywotności, tocząc zaciętą walkę z magnaterią kościelną i świecką, starało się przejść z pańszczyzny na oczynszowanie chłopów”, M. Rękas, Obrońcy chłopów..., s. 133. 
został przejęty od badaczy wcześniejszych generacji, a następnie rozbudowany, także o przeciwstawną obrońcom grupę „twórców reakcyjnych" ${ }^{32}$, i ugruntowany licznymi publikacjami. Schemat ten wpływał zasadniczo na sposób badania tekstów staropolskich poświęconych chłopom. Z punktu widzenia historii literatury ma on jednak kilka niedostatków.

Po pierwsze: im mocniej wierzymy w podział twórców staropolskich na dwa opozycyjne obozy, tym bardziej tracimy z oczu fakt, że przeważająca większość „obrońców chłopów” domagała się poprawy ich losu w obrębie istniejącego systemu prawnego i - co ważniejsze dla badań historycznoliterackich - pojęciowego. Stwierdzenie to nie oznacza, rzecz jasna, postulatu zrewidowania moralnych zasług konkretnych twórców z punktu widzenia dzisiejszych standardów etycznych. Chodzi tu o wskazanie stanowiska wyjściowego dla badań ówczesnej formacji dyskursywnej, w którego świetle rola pisarzy wstawiających się za najniższym stanem wydaje się znacznie bardziej złożona. Nawet bowiem najwięksi „politycy serca”, tacy jak Andrzej Frycz Modrzewski, postulowane idealnie społeczeństwo opierali na istnieniu barier stanowych.

Przyjrzyjmy się pod tym kątem fragmentom dzieł trzech klasycznych obrońców chłopów:

Andrzej Frycz Modrzewski, De Republica emendanda (1551):

Skoro zaś Rzeczpospolita składa się z biednych i majętnych, ze szlachty i plebejuszów, i innych stanów, ma król, jeśli chce, by zapanowała trwała zgoda wśród obywateli, do tego dążyć, aby ustanowić między nimi, o ile to stać się może, równość, ale nie taką, że wszystko tam jest wspólne, albo że da ubogim to, co odebrał bogatym, albo że nieszlachcicom ustąpi przywileje szlachty, albo że zmiesza ze sobą wszystkie stany, lecz taką, że usunie z duszy wszystkich zarozumiałość, butę, pychę i inne takie zarazy ludzką społeczność wprowadzające w zamieszanie. Widzimy, jak ludzie zarażeni

32 Do takich badacze marksistowscy zaliczali między innymi Anzelma Gostomskiego czy Waleriana Nekandę Trepkę, którego Liber generationis plebeanorum (pop. Liber chamorum) - jedyny w swoim rodzaju prześmiewczy spis plebejuszów podających się za szlachtę - doczekał się publikacji dopiero w okresie powojennym. 
takimi wadami jawnie się przechwalają jakowąś nienawistną i nadętą, i dla Rzeczypospolitej zabójczą nierównością $[\ldots]^{33}$.

Fabian Birkowski, Kazania na niedzielę i święta doroczne (1623):

Powiedział Homer, iż Bóg połowicę rozumu bierze od człowieka, gdy niewolnikiem zostaje. Miał rozum przy wolności, już go połowicę traci, gdy w niewoli. A to dlatego, że jest na służbie pańskiej, której k woli rozdzielił rozum swój na poły: sobie połowica, panu połowica dla pańszczyzny. [...] Co jeśli prawda, że niewolnik nie ma więcej rozumu, jedno połowicę, taką rzeczą przyjdzie panu mieć rozum cały jeden i drugiego połowicę, żeby się przypatrzył łasce Bożej, którą Pan Bóg z nim uczynił, gdy go wolnością darował. Bo mogło to być, że się mógł był urodzić chłopem jako drugi. Niechajże ma kompassyją nad sługą swoim, a dziękuje Panu Bogu, że gdy stworzył ludzie wszystkie jednegoż przyrodzenia, z jednego ojca, chciał jednak mieć różnej kondycyjej, jedne pany, jedne sługi ${ }^{34}$.

Szymon Starowolski, Reformacyja obyczajów polskich (ok. 1650):

Natura $\mathrm{z}$ woli Bożej jedne ludzie do posłuszeństwa, a drugie do rozkazowania stworzyła, i te do posłuszeństwa obróciła, które rozumem małym opatrzyła, a owe do rozkazowania, którzy w rozumie i w cnocie przodek przed drugimi mają ${ }^{35}$.

Idealne państwo w ujęciu Modrzewskiego opierało się na pionowej strukturze, w której bynajmniej nie zrównanie stanów, ale moralność poszczególnych członków decydowała o szczęściu wspólnoty. Birkowski różnicę pomiędzy szlachcicem a jego poddanym tłumaczył wolą Bożą, budując przy tym wyrazistą analogię pomiędzy statusem chłopa i antycznego niewolnika. Starowolski powoływał się

${ }_{33}$ A. Frycz Modrzewski, O poprawie Rzeczypospolitej, w: idem, Dzieła wszystkie, t. 1, przeł. E. Jędrkiewicz, wstęp Ł. Kurdybacha, red. i koment. S. Bodniak, Warszawa 1953, s. 129.

${ }^{34}$ F. Birkowski, Kazania na niedzielę i święta doroczne, t. 1, Kraków: Andrzej Piotrkowczyk, 1623, s. 114.

${ }^{35}$ S. Starowolski, Reformacyja obyczajów polskich, [b.m. i r. [ca. 1650]], cyt. za: C. Hernas, Barok, Warszawa 1999, s. 391. 
w tym aspekcie na kategorię natury i wyższość moralno-intelektualną stanów panujących. Podobne przykłady „obrońców chłopów” w różnorodny sposób uzasadniających istnienie poddaństwa można by rzecz jasna mnożyć. Już jednak ta mała garść cytatów pozwala zauważyć, że przeważająca większość twórców zaliczanych do tej grupy odegrała ambiwalentną rolę $\mathrm{w}$ budowaniu dyskursywnego obrazu chłopów. Formułując najrozmaitsze, często bardzo odważne postulaty w sprawie poprawy kondycji najliczniejszego ze stanów, reformatorzy i moraliści umacniali równocześnie zakorzeniony w tradycji antycznej hierarchiczny model pojmowania społeczeństwa ${ }^{36}$. Dążąc więc konsekwentnie do posegregowania tekstów staropolskich na „prochłopskie" i „proszlacheckie”, należałoby linie podziału przeprowadzić wewnątrz samych analizowanych tekstów.

Kolejnym paradoksem dualistycznego modelu jest fakt, że ci sami pisarze mogliby z powodzeniem zostać zaliczeni do grona obrońców chłopów lub ich zdecydowanych opresorów, w zależności od tego, na jakie teksty powołałby się autor konstruowanej w ten sposób nar-

${ }^{36}$ Nie mogło być inaczej w sytuacji, w której najpopularniejsze toposy konceptualizujące społeczeństwo wywodziły się z tradycji antycznej, dla której niewolnictwo było naturalnym kontekstem. Zob. uwagi I. Chrzanowskiego: „Wszyscy oni [pisarze staropolscy - J.K.-S.] obstają za tym, że się różnice społeczne ostać powinny, że nierówność praw politycznych jest nie tylko niezbędnym warunkiem pomyślności państwa i społeczeństwa, ale co więcej, ustanowieniem bożym. Uczyli tego zarówno pisarze katoliccy, jak protestanccy, powołując się to na Arystotelesa, który usprawiedliwiał niewolnictwo, to na Platona, który przesunięcie granic między stanami poczytywał za największe niebezpieczeństwo dla państwa, to na Cycerona, który dowodził, że równość praw politycznych jest szkodliwym urojeniem; przybiegł na pomoc św. Augustyn ze swoją nauką o niewolnictwie jako karze bożej za grzech [...] oraz św. Tomasz ze swą nauką na Arystotelesie opartą, że niewolnictwo nie jest wprawdzie sprawiedliwością absolutną, ale jest sprawiedliwością względną", I. Chrzanowski, Wstęp, w: P. Skarga, Kazania sejmowe, oprac. I. Chrzanowski, Warszawa 1912, s. 114. Jedynie teksty, które nie odwołują się do tych tradycyjnych modeli opisu społeczeństwa, mogły wykroczyć poza ambiwalentny model moralistyki domagającej się reform w obrębie istniejącej hierarchii stanowej. W takim kontekście można, moim zdaniem, odczytywać obrony chłopów przeprowadzone z poziomu dyskursu teologicznego przez radykalny odłam braci polskich. 
racji historycznej. Przyjrzyjmy się dwóm wymownym przykładom. Pierwszym z nich jest Stanisław Orzechowski, uchodzący przez lata za modelowy przykład ideologa szlacheckiego ${ }^{37}$. W kontekście poglądów społecznych tego pisarza przywoływano najczęściej fragmenty Policyi Królestwa polskiego (powst. 1566), w której na rozmaite sposoby dowodził on niezacieralnej różnicy pomiędzy bene nati a plebei. Oto jeden $\mathrm{z}$ nich:

A jako sługa służbą gospodarską $\mathrm{w}$ domu zniewolonym będąc, równym gospodarzowi ani dzieciom jego nie jest [...] tak też kmieć, rzemieślnik, kupiec, służbą koronną zniewolonymi ludźmi będąc, nie mogą tejże ceny w koronie polskiej być, której jest kapłan i król z rycerstwem koronnym; które rycerstwo przez wysokość wolności i cnoty swej to jest herbem [...] jako piątnem napiątnowane od Boga przez zwierzchni urząd jest, którego herbu kmieć, rzemieślnik, kupiec prze to w Polszce nie ma, iż prawda z kupią nie mieszka pospołu, bo i Bóg mówi: „non potestis Deo servire et mamonae", to jest nie możecie razem Bogu, to jest prawdzie służyć i kupczyćs ${ }^{38}$.

Zawarta w przytoczonym fragmencie parafraza urywku Polityki Arystotelesa (dotyczącego pozycji niewolnika w rodzinie), wzmocniona dodatkowo autorytetem tekstu biblijnego, pozwala Orzechowskiemu zbudować perswazyjny wywód wyłączający stany plebejskie $\mathrm{z}$ istotnego udziału w państwie. Mistyczny herb - symbol cnoty przekładającej się na władzę - przynależy wyłącznie szlachcie, gdyż

[...] wszystek stan rycerski usiadł na prawdzie i na wierze, które cnoty dwie, mówiąc o nich właśnie, brzydzą się wszytkimi pieniężnymi obchody, które

${ }^{37}$ Zob. M. Ludwikowska, R.R. Ludwikowski, Stanisław Orzechowski - prekursor szlacheckiego anarchizmu, „Zeszyty Naukowe Uniwersytetu Jagiellońskiego. Prace Prawnicze" 86 (1980); J. Nowak-Dłużewski, Stanisław Orzechowski - pisarz nieznany, w: „Przegląd Humanistyczny” 3 (1965); T. Sinko, Erudycja klasyczna Stanistawa Orzechowskiego, Kraków 1939.

${ }^{38}$ S. Orzechowski, Policyja Królestwa Polskiego, oprac. J. Starnawski, w: Stanisław Orzechowski. Pisarz polityczny. Materiaty z konferencji naukowej w pięćsetlecie urodzin renesansowego humanisty. Przemyśl-Żurawica 17-18 października 2013, red. J. Musiał, Przemyśl 2014, s. 162-163. 
też za złą a mierzioną rzecz zysk pieniężny u siebie ma, tak iż też Franciszek ś(więty) w zakonie swym braty swe, nie tylko mieć pieniądze, ale i dotykać pieniędzy zakazał. Czemu? Przeto, iż jako z dotykania niewieściego ciała hnet żądło ono przyrodzone przeciwko niewieście w nas wstaje, tak też z dotykania pieniądza zapala się chuć w nas przeciwko pieniądzom lakoma ${ }^{39}$.

Ten bardzo pomysłowy w swojej argumentacji wywód niewiele ma wspólnego z współczesną Orzechowskiemu rzeczywistością, w której podstawą ekonomicznego bytu szlachty był przecież handel zbożowy. Pisarz nie opisuje jednak otaczających go realiów społecznych, ale konstruuje dyskursywną machinę uzasadniającej wyłączność władzy szlacheckiej. Łatka antyplebejskiego ideologa wydaje się zatem uzasadniona. Cóż jednak zrobić z faktem, że ten sam Orzechowski jest autorem jednego z najodważniejszych postulatów reformatorskich w sprawie chłopskiej?

Okrutna rzecz jest wyciskać podatki z tych, co sami nic nie mają; nakładać na nich te koszta obrony, kiedy już i tak upadają pod ciężarem robocizny i różne służebności, które panom swoim składać muszą. A oprócz panów jeszcze przeróżne daniny i opłaty [...] składać muszą księżom. A przecie to oni są fundamentem Rzeczypospolitej, oni uprawiają ziemię, $\mathrm{z}$ ich pracy żyje za darmo wszelkie stworzenie. [...] I jeszcze na nich zwalać ten ciężar obrony Rzeczypospolitej? Nie tak - nie tak zaiste przodkowie nasi założyli tę Rzeczypospolitą! Podług ich myśli szlachcic miał bronić, a chłop z uprawianej czynsz mu płacić. A myśmy zwalili wszystko na rolnika jednego. A co na to powie Pan Bóg? Jeśli nie sprawiedliwość i wstyd, to strach Jego kar powinien by nas opamiętać ${ }^{40}$

- to fragment ogłoszonej w 1543 roku Mowy Rzeczypospolitej ${ }^{41}$. Nie sposób zaprzeczyć, że w przypadku tego tekstu pomysłowość

39 Ibidem, s. 163.

40 S. Orzechowski, Respublica Polona proceribus polonis in conventu generali [...], cyt. za: S. Tarnowski, Pisarze polityczni XVI wieku, Kraków 2000, s. 113-114.

${ }^{41}$ Komentując powyższy passus, Stanisław Tarnowski stwierdzał, że apel o całkowite uwolnienie ludności chłopskiej od podatków był ewenementem w skali europejskiej, zob. S. Tarnowski, Pisarze polityczni..., s. 113. 
Orzechowskiego w warstwie inwencyjnej (m.in. sięgnięcie po topos przodków - założycieli państwa), a także nagromadzenie wyrazistych środków stylistycznych (pytania retoryczne, wykrzyknienia) służą nakłonieniu słuchaczy do podjęcia konkretnych działań mających na celu polepszenie kondycji poddanych. Byłżeby więc Orzechowski także „politykiem serca”?

Przykład drugi. Cytowany w licznych antologiach obrońców chłopów Wacław Potocki pojawia się w nich jako wybitny satyryk, szczególnie udatnie krytykujący nadużycia feudalizmu ${ }^{42}$. Istotnie, w licznych moralizujących utworach o tematyce społecznej poeta kreślił pełen sugestywnych szczegółów, poruszający obraz chłopskiej niedoli:

Szlachta w strojach, w bankietach gdy chce równać z pany,

$\mathrm{W}$ ustawicznych podatkach zniszczał ich poddany,

Nie wiedząc na co pierwej płonnych lat użytki,

Żołnierzom na zasługi czy panom na zbytki,

Czy na się przy codziennej ciężkiej robociźnie

Łożyć ma, tak się z nimi obchodzimy zgryźnie.

Zwłaszcza gdy zboże nizacz abo w małej cenie,

Wielkim nierządem, samo cenę ma odzienie,

Które kupić dla dzieci, dla czeladzi trzeba,

Choć drugi nie skosztuje swojej prace chleba.

Oni nas żywią, bronią, strzegą, a co ciężej:

Oni za nas żołnierzom, oni płacą księżej.

Nikt prócz nich Boskiej kary nie ponosi zgoła ${ }^{43}$.

Nie sposób jednak zgodzić się z redaktorami Antologii poezji walczącej o postęp $i$ wyzwolenie społeczne, którzy we wstępie do tej publikacji przypisywali Potockiemu ariańską koncepcję stosunku do

${ }^{42}$ S. Czernik, J, Przyboś, Wstęp, s. 10; M. Piszczkowski, Nota Wydawcy, w: Obrońcy chłopów w literaturze..., s. 74.

${ }^{43}$ W. Potocki, Na Orła polskiego, w: idem, Wiersze wybrane, oprac. S. Grzeszczuk, Wrocław 1992, s. 242. Wiele innych utworów Potockiego piętnujących nadużycia systemu pańszczyźnianego zebrał w osobny cykl zatytułowany Obrońca chłopów Jan Dürr-Durski, zob. W. Potocki, Pisma wybrane, oprac. J. Dürr-Durski, t. 1, Warszawa 1953, s. 329-355. 
chłopów opierającą się na naturalnej równości społecznej wszystkich ludzi ${ }^{44}$. Poeta ma bowiem w swoim dorobku także niezwykle charakterystyczny cykl wierszy piętnujący plebejuszy (chłopów i mieszczan) usiłujących przedostać się w uprzywilejowane szeregi stanu szlacheckiego. Jednym z nich jest włączony do Moraliów wiersz Znam cię po sierci:

Po sierci poznać konie, do czego z natury:

Czy pod wierzch sposobniejszy będzie, czy do fury.

[...]

Nikogo herbem zamsik i chłop nie oszuka,

Choćby chciał, bo go wyda, jak się rodził, suka ${ }^{45}$.

Już ten krótki fragment antyplebejskiego pamfletu pozwala zauważyć, że przy całym krytycznym stosunku Potockiego do oburzających go moralnie stosunków pańszczyźnianych bariery społeczne przedstawia on w kategoriach quasi-biologicznych różnic pomiędzy poszczególnymi stanami i niezwykle dosadnie piętnuje próby ich przekroczenia. Temperaturę tych wierszy można by z powodzeniem porównać do ekspresyjnych fragmentów Liber chamorum Waleriana Nekandy Trepki - jedynego w swoim rodzaju pomnika szlacheckiej pogardy dla stanów plebejskich. Do którego więc z dwóch opozycyjnych obozów zaliczyć Potockiego?

Odpowiedź nasuwa się sama: to ramy interpretacyjne dzielące pisarzy staropolskich na obrońców i ciemiężycieli chłopów nie przystają gładko do tekstów poruszających problematykę najliczniejszego ze stanów. Ten sam pisarz, co więcej, ten sam tekst mógł zarówno wyrażać ekskluzywizm szlachecki, jak i wskazywać konkretne wady istniejącego porządku społecznego. Jednym z podstawowych mechanizmów ówczesnej prozy politycznej, parenetyki czy satyry była bowiem moralistyka dopuszczająca daleko posuniętą krytykę wad

44 S. Czernik, J. Przyboś, Wstęp, s. 10.

${ }^{45}$ W. Potocki, Znam cię po sierci, w: idem, Moralia i inne utwory $z$ lat 16881696, oprac. L. Kukulski, Warszawa 1987, s. 141. 
systemu społecznego przy równoczesnym aprobowaniu podstawowych jego założeń i kategorii pojęciowych.

Ostatnim, choć nie najmniej istotnym problemem metodologicznym, który należy poruszyć, omawiając binarny model historii chłopów, jest fakt, że schemat ten w dużym stopniu wymusza formułowanie rozstrzygających sądów o osobistych poglądach samych autorów tekstów. Jak bardzo jest to niekiedy skomplikowane, pokazuje przypadek Łukasza Górnickiego. Jego stanowisko w sprawie chłopskiej wywołało swego czasu znamienną polemikę wśród historyków. Aleksander Świętochowski w Historii chłopów polskich stwierdzał, że autor Dworzanina reprezentował w tej kwestii poglądy typowe dla oświeconej warstwy szlacheckiej, w czym „odchylił się od pionu opinii znakomitych pisarzy XVI w." ${ }^{\prime \prime 6}$.Uczony powoływał się na następujący fragment Rozmowy Polaka $z$ Włochem (powst. 1588-1598):

Włoch: Tak ci mówią niektórzy z waszych, iż tu w Polszcze jedni ludzie są w wielkiej niewoli, a drudzy w wielkiej swejwoli, a przecię i ci, którzy są w swejwoli, czują wielką niewolą.

Polak: Tak jest, iż plebs u nas nie zażywa wolności, ale jej też chłopstwu nie trzeba, bo wolność byłaby ku ich skazie. Kto dusze swej używać nie umie, temu lepiej, żeby jej nie miał a był umarłym niż żywym, a jeśli tego potrzeba, iżby taki człowiek był żyw, tedy lepiej, żeby był niewolnikiem niż wolnym człowiekiem. I dziecięciu wolności nie dajemy, bo go chciwości sprawują, nie rozum; także też wolności ten nie godzien, kogo ciało, a nie dusza sprawuje $e^{47}$.

Z taką kwalifikacją stanowiska Górnickiego nie zgodził się z kolei Mieczysław Piszczkowski, który stwierdził, że w przywołanym przez Świętochowskiego dialogu politycznym poglądy autora reprezentuje nie Polak, lecz Włoch. Uznawszy więc opinię poprzednika za nie-

46 A. Świętochowski, Historja chłopów polskich..., s. 205.

47 Ł. Górnicki, Rozmowa Polaka $z$ Włochem o wolnościach i prawach polskich, w: idem, Pisma, oprac. R. Pollak, t. 2, Warszawa 1961, s. 348-349. 
ścisłą, włączył Górnickiego w liczbę obrońców chłopów ${ }^{48}$. Rzut oka na inny fragment tego samego dzieła pozwala jednak stwierdzić, że zakładany porte-parole autora reprezentuje w kwestii chłopskiej stanowisko co najwyżej umiarkowane. Tak oto przedstawia się passus dotyczący kary za mężobójstwo:

P. Byś ty miał rozum Salomonowy, tedy ja tobie tego nie pozwolę, żeby to dobrze być u nas miało, głowa za głowę, a zwłaszcza żeśmy nie wszyscy jednacy: ina chłop, a ina szlachcic.

W. Nic ja tu nie mówię o chłopach (aczci filozof chce to mieć, iżby barziej bogatego karano, gdy ubogiemu czyni krzywdę, niż gdy między sobą jeden drugiemu onę uczyni), niechaj między chłopy płacenie głów będzie i majdeburskie prawo, które się też czartu godzi, niech przy nich zostanie; ale ja mówię o szlachcie i dziwuję się, czemuście na się tak głupie postanowili prawo ${ }^{49}$.

Ekskluzywizm stanowy reprezentowany jest zatem wyraźnie także w słowach Włocha. Jakie zaś poglądy w tej mierze wyznawał sam Górnicki, który ostatecznie na drodze nobilitacji dostał się w szlacheckie szeregi? Wydaje się, że określenie stanowiska pisarza na podstawie samego tekstu jest tutaj bardzo trudne, tym bardziej że konwencja gatunkowa dialogu nie wymusza formułowania stanowiska autorskiego (a jedynie retoryczne starcie odmiennych poglądów).

Dualistyczny model historii chłopów przez dziesięciolecia determinował sposób badania tekstów staropolskich poruszających problem najliczniejszego ze stanów. Powstały w ten sposób specyficzne ramy narracyjne, decydujące zarówno o doborze źródeł, jak i o sposobie ich interpretacji ${ }^{50}$. Wydaje się, że chociażby ze względu na

${ }^{48}$ Zob. uwagi M. Piszczkowskiego w cytowanej Nocie wydawcy do Obrońców chłopów w literaturze polskiej, s. 70.

49 Ł. Górnicki, Rozmowa..., s. 393-394.

${ }^{50}$ Warto zasygnalizować, że z dualistycznej ramy interpretacyjnej obrońcaopresor rezygnowały niektóre ujęcia folklorystyczne. Bardzo ciekawą propozycją interpretacyjną w zakresie obrazowania chłopów w tekstach dawnych jest studium Czesława Hernasa U źródeł folklorystyki polskiej, Warszawa 1965. Figurą obrońców posługiwał się natomiast w niektórych swoich szkicach Julian Krzyżanowski, zob. 
wskazane powyżej problemy metodologiczne najwyższy czas zrezygnować z dzielenia pisarzy staropolskich na obrońców i ciemiężycieli chłopów, a ich tekstów na obronne i opresyjne. Segregacja ta, jak starałam się wykazać na podstawie przytoczonych powyżej przykładów, utrudnia zrozumienie, że przeważająca większość dzieł opisujących stan chłopski, lub szerzej - hierarchiczny model społeczeństwa, cechowała się przede wszystkim głęboką ambiwalencją. Nie negując zasług poszczególnych pisarzy w sprawie chłopskiej, warto, jak sądzę, przekroczyć poziom moralnej oceny ich dzieł i skierować uwagę przede wszystkim na same teksty i ich analizę. Ciekawą inspiracją metodologiczną dla takich rozpoznań mogłaby być na przykład imagologia badająca dyskursywne reprezentacje grup narodowych w kategoriach tropów ${ }^{51}$. Inną, być może bliższą historykom literatury, propozycją mogłaby być analiza podstawowych toposów, po jakie sięgali pisarze, mówcy czy kaznodzieje opisujący chłopów. Jednym $\mathrm{z}$ takich loci communes było na przykład porównanie społeczeństwa do organizmu ludzkiego, pojawiające się w tekstach dawnych zarówno w funkcji obrony najniższych stanów (by zachować integralność ciała społecznego), jak i w celu uzasadnienia „naturalnej różnicy” pomiędzy ludźmi ${ }^{52}$. Jest to jeden $\mathrm{z}$ wielu przykładów dowodzących, że ambiwalentny stosunek elit intelektualnych do stanów plebejskich zakorzeniony był już w samym ówczesnym języku i popularnych konwencjach estetycznych. Niezależnie od wyboru metody warto, ażeby studia chłopskie w ogóle pojawiły się w perspektywie badań nad historią literatury staropolskiej. Obecnie można odnieść wraże-

J. Krzyżanowski, Szkice folklorystyczne, t. 1, Kraków 1980, s. 405-417. Omówienie wszystkich badań uwzględniających „głos wykluczonych” (źródła etnograficzne, dokumenty życia chłopskiego, literaturę plebejską) wykracza jednak poza ramy niniejszego artykułu, skupiającego się na tekstach staropolskich konstruujących dyskurs o chłopie z zewnętrznej perspektywy władzy/wiedzy.

51 J. Leerssen, Imagology. History and Metod, w: Imagology. The Cultural Construction and Literary Representation of National Characters. A Critical Survey, ed. by M. Beller, J. Leerssen, Amsterdam 2007, s. 28.

52 C. Hernas, $U$ źródeł folklorystyki..., s. 84. 
nie tabuizacji tej problematyki w obrębie dyscypliny. Moralna ocena pańszczyźnianego dziedzictwa stanowi, jak wiadomo, gorący temat burzliwych publicystycznych sporów, wyraźnie zogniskowanych wokół dwóch zwalczających się obozów ${ }^{53}$. Perspektywa posądzenia o przynależność do jednego z nich z pewnością nie zachęca współczesnych historyków literatury do podejmowania refleksji w tym zakresie. Temat chłopów nadal jawi się jako historycznie i politycznie uwikłany. Niezależnie jednak od tego istotnie dość skomplikowanego kontekstu subdyscypliny, jaką mogłyby być staropolskie peasant studies, ich zainicjowanie wydaje się ze wszech miar pożądane. Stan chłopski był przecież jedną z podstawowych kategorii wczesnonowożytnej rzeczywistości społecznej. Trudno więc wyobrazić sobie pełny opis kultury czy literatury staropolskiej starannie omijający tę kategorię.

${ }^{53}$ Pierwszy z nich domaga się przepracowania historii chłopów jako wypartego „ciemnego dziedzictwa” naszej historii, zob. A. Pacholski, Jak Polak zhańbił Polaka, czyli niewolnictwo po polsku, „Gazeta Wyborcza” nr 198 z 2.08. 2012, http://wyborcza. pl/magazyn/1,124059,12346425,Jak_Polak_zhanbil_Polaka_czyli_niewolnictwo_ po_polsku.html (dostęp: 28.01.2019); idem, Chata wuja Chama, „Gazeta Wyborcza” nr 138 z 14.06.2014, http://wyborcza.pl/magazyn/1,124059,14100485,Chata_wuja_ chama.html (dostęp: 28.01.2019); J. Majmurek, Potomek chłopów pańszczyźnianych patrzy na Wilanów, „Krytyka Polityczna” nr 29 z 25.05.2013, http://krytykapolityczna.pl/kraj/majmurek-potomek-chlopow-panszczyznianych-patrzy-na-wilanow/ (dostęp: 28.01.2019). Drugi zaś usiłuje podważyć zbyt krytyczną - w tym ujęciu ocenę relacji społecznych w dawnej Rzeczypospolitej, zob. M. Agnosiewicz, Mit niewolnictwa pańszczyźnianego chłopa, http://www.racjonalista.pl/kk.php/s,10002 (dostęp: 18.01.2019); W. Knap, Mity mocne jak chłop polski, „Dziennik Polski” 10.02.2015, https://dziennikpolski24.pl/mity-mocne-jak-chlop-polski/ar/3745751 (dostęp: 28.01.2019). 


\section{Bibliografia}

\section{Źródła}

Birkowski F., Kazania na niedzielę i święta doroczne, t. 1, Kraków: Andrzej Piotrkowczyk, 1623.

Frycz Modrzewski A., O poprawie Rzeczypospolitej, w: idem, Dzieła wszystkie, t. 1, przeł. E. Jędrkiewicz, wstęp Ł. Kurdybacha, red. i koment. S. Bodniak, Warszawa 1953.

Górnicki Ł., Rozmowa Polaka z Włochem o wolnościach i prawach polskich, w: idem, Pisma, oprac. R. Pollak, t. 2, Warszawa 1961.

Orzechowski S., Policyja Królestwa Polskiego, oprac. J. Starnawski, w: Stanisław Orzechowski. Pisarz polityczny. Materiały z konferencji naukowej w pięćsetlecie urodzin renesansowego humanisty. Przemyśl-Żurawica 17-18 października 2013, red. J. Musiał, Przemyśl 2014.

Potocki W., Na Orła polskiego, w: idem, Wiersze wybrane, oprac. S. Grzeszczuk, Wrocław 1992.

Potocki W., Pisma wybrane, oprac. J. Dürr-Durski, t. 1, Warszawa 1953.

Potocki W., Znam cie po sierci, w: idem, Moralia $i$ inne utwory z lat 1688-1696, oprac. L. Kukulski, Warszawa 1987.

Starowolski S., Reformacyja obyczajów polskich, [b.m. i r. [ca 1650]].

„Wzięli diabli pana”. Antologia poezji walczacej o postęp $i$ wyzwolenie społeczne 1543-1953, oprac. S. Czernik, J. Przyboś, Warszawa 1955.

\section{Opracowania}

Baczewski S., Obraz plebejusza w literaturze szlacheckiej: rekonesans, „Napis. Pismo poświęcone literaturze okolicznościowej i użytkowej” 15 (2009).

Chemperek D., Z chłopki księżna. Historia wielkiej mistyfikacji XVII wieku, Lublin 2000.

Chrzanowski I., Wstęp, w: P. Skarga, Kazania sejmowe, oprac. I. Chrzanowski, Warszawa 1912.

Czernik S., Pięć wieków doli chłopskiej w literaturze XII-XVI wieku. Materiały i szkice, Warszawa 1953.

Czernik S., Z życia pańszczyźnianego w XVII wieku. Materiały i szkice, Warszawa 1955.

Czernik S., Przyboś J., Wstęp, w: „Wzięli diabli pana”. Antologia poezji walczącej o postęp i wyzwolenie społeczne 1543-1953, oprac. S. Czernik, J. Przyboś, Warszawa 1955.

Engelking A., „Poleszczuk” nieoswojony. Wokół funkcji chłopskości w konstruowaniu polskości, „Teksty Drugie” 6 (2017): Chłopskość. 
Gołębiowska Z., Jak pisać historię chłopów polskich? Uwagi i refleksje Stanisława Egberta Koźmiana, „Annales Universitatis Mariae Curie-Skłodowska. Sectio F” 54/55 (1999/2000).

Gorzycki K.J., Zarys historii chłopów w dawnej Polsce do zniesienia poddaństwa, Warszawa 1902.

Grzeszczuk S., Obrońcy chłopów w piśmiennictwie staropolskim, w: idem, Materiały do studiowania literatury staropolskiej, cz. 1, Rzeszów 1976.

Hernas C., Barok, Warszawa 1999.

Hernas C., U źródet folklorystyki polskiej, Warszawa 1965.

Historia chłopów polskich, t. 1: Do upadku Rzeczypospolitej szlacheckiej, red. S. Inglot, oprac. J. Burszta et al., Warszawa 1970.

Instrukcje S.E. Koźmiana, Biblioteka Naukowa PAN i PAU w Krakowie, sygn. BPANKr, rkps 2212/7.

Kot S., Polska rajem dla Żydów, piekłem dla chłopów, niebem dla szlachty, Warszawa 1937.

Kot S., Urok wsi i życia ziemiańskiego w poezji staropolskiej, Warszawa 1937.

Krzyżanowski J., Szkice folklorystyczne, t. 1, Kraków 1980.

Kuligowski W., Chamska historia Polski. Tezy i antytezy, „Czas Kultury” 3 (2016).

Leerssen J., Imagology. History and Metod, w: Imagology. The Cultural Construction and Literary Representation of National Characters. A Critical Survey, ed. by M. Beller, J. Leerssen, Amsterdam 2007.

Lelewel J., Uwagi nad dziejami Polski i ludu jej, w: idem, Polska. Dzieje i rzeczy jej rozpatrywane, t. 3, Poznań 1855.

Lubomirski J.T., Rolnicza ludność w Polsce od XVI do XVIII wieku, Warszawa 1862.

Ludwikowska M., Ludwikowski R.R., Stanisław Orzechowski - prekursor szlacheckiego anarchizmu, „Zeszyty Naukowe Uniwersytetu Jagiellońskiego. Prace Prawnicze" 86 (1980).

Maciejowski W.A., Historya włościan i stosunków ich politycznych, społecznych i ekonomicznych, które istniały w Polsce od czasów najdawniejszych aż do drugiej potowy XIX wieku, Warszawa 1874.

Matuszewski J., Cham, Łódź 1991.

Nartowski W., Stan włościański w utworach poetyckich pisarzy polskich doby renesansowej (XVI wieku), „Lud. Kwartalnik etnograficzny” 19 (1913).

Nowak-Dłużewski J., Stanisław Orzechowski - pisarz nieznany, „Przegląd Humanistyczny" 3 (1965).

Obrońcy chłopów w literaturze polskiej, zest. i oprac. M. Piszczkowski, Kraków 1951.

Piszczkowski M., Nota Wydawcy, w: Obrońcy chłopów w literaturze polskiej, zest. i oprac. M. Piszczkowski, Kraków 1951.

Pobłocki K., Niewolnictwo po polsku, „Czas Kultury” 3 (2016).

Przyborowski W., Włościanie u nas i gdzieindziej. Szkice historyczne, Wilno 1881.

Rękas M., Obrońcy chłopów w dobie polskiego Odrodzenia, Warszawa 1954.

Sinko T., Erudycja klasyczna Stanisława Orzechowskiego, Kraków 1939. 
Stawski E., Poszukiwania do historyi rolnictwa krajowego, Warszawa 1858.

Szczotka S., Lament chłopski na pany oraz inne narzekania na niedole poddanych polskich, Warszawa 1946.

Świętochowski A., Historja chłopów polskich w zarysie, t. 1, Lwów 1925.

Tarnowski S., Pisarze polityczni XVI wieku, Kraków 2000.

„Teksty Drugie” 6 (2017): Chłopskość.

Tomczok P., Pańszczyzna i przemoc. Historie literackie i wspomnieniowe z XIX wieku, „Praktyka Teoretyczna” 1 (2017).

Urbanek M., Chłop w literaturze złotego okresu, w: Sprawozdania dyrekcji c. k. Gimnazyum w Sanoku za lata szkolne 1913/1914 i 1915/1916.

Wieś pańszczyźniana w literaturze polskiej (w. XV-XIX), oprac. i wstęp M. Piszczkowski, Warszawa 1972.

\section{Teksty publicystyczne}

Agnosiewicz M., Mit niewolnictwa pańszczyźnianego chłopa, http://www.racjonalista.pl/kk.php/s,10002 (dostęp: 18.01.2019).

Knap W., Mity mocne jak chłop polski, „Dziennik Polski” 10.02.2015, https://dziennikpolski24.pl/mity-mocne-jak-chlop-polski/ar/3745751 (dostęp: 28.01.2019).

Majmurek J., Potomek chłopów pańszczyźnianych patrzy na Wilanów, „Krytyka Polityczna” nr 29 z 25.05.2013, http://krytykapolityczna.pl/kraj/majmurek-potomek-chlopow-panszczyznianych-patrzy-na-wilanow/ (dostęp: 28.01.2019).

Pacholski A., Chata wuja Chama, „Gazeta Wyborcza” nr 138 z 14.06.2014, http://wyborcza.pl/magazyn/1,124059,14100485,Chata_wuja_chama.html(dostęp:28.01. 2019).

Pacholski A., Jak Polak zhańbił Polaka, czyli niewolnictwo po polsku, „Gazeta Wyborcza” nr 198 z 2.08. 2012, http://wyborcza.pl/magazyn/1,124059,12346425,Jak_Polak_zhanbil_Polaka_czyli_niewolnictwo_po_polsku.html (dostęp: 28.01.2019). 